\title{
Health care for children and adolescents in Poland
}

\author{
Grażyna Hejda', Artur Mazur², Łukasz Dembiński³, Jarosław Peregud-Pogorzelski, \\ Teresa Jackowska ${ }^{5}$, Mieczysław Walczak $^{6}$, Tomasz Szczepański ${ }^{7}$ \\ 'Institute of Nursing and Health Sciences, Faculty of Medicine, University of Rzeszow, Rzeszow, Poland \\ ${ }^{2}$ Department of Paediatrics, Paediatric Endocrinology, and Diabetes, Faculty of Medicine, University of Rzeszow, Rzeszow, \\ Poland \\ ${ }^{3}$ Department of Paediatric Gastroenterology and Nutrition, Medical University of Warsaw, Warsaw, Poland \\ ${ }^{4}$ Department of Paediatrics, Paediatric Oncology, and Immunology, Pomeranian Medical University, Szczecin, Poland \\ ${ }^{5}$ Department of Paediatrics, Medical Centre of Postgraduate Education, Warsaw, Poland \\ ${ }^{6}$ Department of Paediatrics, Endocrinology, Diabetology, Metabolic Diseases, and Cardiology of Developmental Age, \\ Pomeranian Medical University, Szczecin, Poland \\ ${ }^{7}$ Department of Paediatric Haematology and Oncology, School of Medicine with the Division of Dentistry in Zabrze, \\ Medical University of Silesia in Katowice, Poland
}

\section{ABSTRACT}

Despite the constant tendency of decreasing birth rate, children and adolescents comprise one fifth of the Polish population. Health care for children is free and it is organised similarly to the care for adult patients. In primary health care, children can be under the medical care of general practitioners, family doctors, or paediatricians. In secondary and tertiary care, medical services are provided by paediatricians or doctors with paediatric subspecialties. The number of paediatricians and nurses is not sufficient and still differs from the European average. Nonetheless, population health indicators (e.g. infant mortality rate) are constantly improving and, despite the strong influence of the anti-vaccine movements, $90 \%$ of children are vaccinated according to the schedule.

KEY WORDS:

health care, children, adolescents.

\section{INTRODUCTION}

Under Polish law, the right to health protection is guaranteed in Article 68 of the Constitution of the Republic of Poland of 1997. This article additionally contains a provision obliging public authorities to provide special health care to children [1].

The child's right to health protection is also safeguarded by international treaties, in particular by the United Nations Convention on the Rights of the Child (CRC, General Assembly of the United Nations, November 20, 1989) ratified by Poland in 1991, which among the rights of the child lists also the right to the best health care and facilities for the treatment of diseases and rehabilitation [2].

The health care system in Poland is based on the national social health insurance model, in which the main source of financing is an obligatory monthly fee calculated as a percentage of people's salary. The National Health Fund (NFZ) is a disposer of these funds acting in the system as the main payer. The costs of outpatient and stationary health care are covered by the NFZ in the form of a lump sum, a fee for a patient, or for specific services [3].

\section{ADDRESS FOR CORRESPONDENCE:}

Artur Mazur, Department of Paediatrics, Paediatric Endocrinology, and Diabetes, Faculty of Medicine,

University of Rzeszow, 60 Lwowska St., 35-301 Rzeszów, Poland, ORCID: 0000-0001-5393-3515,

e-mail:drmazur@poczta.onet.pl 
TABLE 1. Population and health status indicators of children in Poland in the years 1990-2017

\begin{tabular}{|c|c|c|c|c|c|c|c|}
\hline Characteristics & 1990 & 1995 & 2000 & 2005 & 2010 & 2015 & 2017 \\
\hline Total population & $38,073,000$ & $38,284,000$ & $38,253,955$ & $38,157,055$ & $38,529,866$ & $38,437,239$ & $38,433,558$ \\
\hline $\begin{array}{l}\text { Number of children and adolescents } \\
\text { aged } 0-19\end{array}$ & $12,183,000$ & $11,914,891$ & $10,636,821$ & $9,058,458$ & $8,280,106$ & 7732,280 & 7689,955 \\
\hline $\begin{array}{l}\text { Percent of children and adolescents } \\
\text { aged } 0-19\end{array}$ & 32.0 & 31.1 & 27.8 & 23.5 & 21.5 & 20.1 & 20.0 \\
\hline Number of children aged $0-14$ & $9,495,000$ & $8,678,164$ & $7,294,451$ & $6,189,175$ & $5,855,766$ & $5,754,564$ & $5,824,219$ \\
\hline Percent of children aged $0-14$ & 24.9 & 22.7 & 19.1 & 16.2 & 15.2 & 15.0 & 15.2 \\
\hline Live births & 547,720 & 433,109 & 378,348 & 364,383 & 413,300 & 369,308 & 401,982 \\
\hline Dead births & 3940 & 3206 & 2128 & 1712 & 1730 & $1075^{*}$ & $1101^{*}$ \\
\hline Infant deaths (per 1000 live births) & 19.3 & 13.6 & 8.1 & 6.4 & 5.0 & 4.0 & 4.0 \\
\hline $\begin{array}{l}\text { Infant deaths in cities } \\
\text { (for } 1000 \text { live births) }\end{array}$ & 19.1 & 13.7 & 8.3 & 6.3 & 5.0 & 4.0 & 3.9 \\
\hline $\begin{array}{l}\text { Infant deaths in the countryside } \\
\text { (for } 1000 \text { live births) }\end{array}$ & 19.7 & 13.5 & 7.9 & 6.5 & 5.0 & 4.1 & 4.1 \\
\hline $\begin{array}{l}\text { Deaths of male infants } \\
\text { (per } 1000 \text { live births) }\end{array}$ & ND & ND & 8.8 & 7.0 & 5.4 & 4.4 & 4.4 \\
\hline $\begin{array}{l}\text { Deaths of female infants } \\
\text { (per } 1000 \text { live births) }\end{array}$ & ND & ND & 7.3 & 5.9 & 4.5 & 3.6 & 3.6 \\
\hline Neonatal deaths (per 1000 live births) & ND & ND & 5.6 & 4.5 & 3.5 & 2.9 & 2.8 \\
\hline $\begin{array}{l}\text { Deaths of children under the age of } 5 \\
\text { (per } 1000 \text { live births) }\end{array}$ & ND & ND & ND & 7.5 & 5.8 & 4.7 & 4.6 \\
\hline $\begin{array}{l}\text { Deaths of boys under the age of } 5 \\
\text { (per } 1000 \text { live births) }\end{array}$ & ND & ND & ND & 8.1 & 6.2 & 5.2 & 5.1 \\
\hline $\begin{array}{l}\text { Deaths of girls under the age of } 5 \\
\text { (for } 1000 \text { live births) }\end{array}$ & ND & ND & ND & 6.8 & 5.3 & 4.2 & 4.1 \\
\hline Perinatal mortality (per 1000 births) & 19.5 & 15.3 & 9.7 & 8.0 & 6.0 & $5.0^{*}$ & $4.8^{*}$ \\
\hline $\begin{array}{l}\text { Deaths of infants over } 30 \text { days of life } \\
\text { (per } 1000 \text { live births) }\end{array}$ & ND & ND & 2.5 & 1.9 & 1.5 & 1.1 & 1.2 \\
\hline
\end{tabular}

estimated data

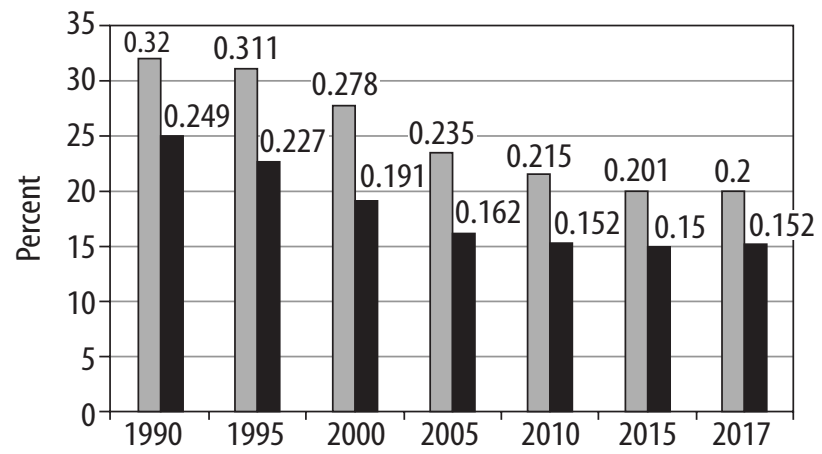

$\square$ Percent of children and adolescents aged $0-19$

- Percent of children aged 0-14

FIGURE 1. Percentage of children and adolescents in the total population in Poland in the years 1990-2017

According to Polish law, every child (in legal terms, any person under 18 years old) has the right to free health care, regardless of his/her or their parents' insurance status. A child as a patient is entitled to at least the same rights as an adult, subject to the limitations resulting from their age and the rights of their parents or legal guardians.

\section{DEMOGRAPHIC CHARACTERISTICS}

Since 2010, the population of Poland has been slowly but gradually decreasing from $38,539,862$ in 2010 to $38,433,558$ in 2017 (Table 1). At the same time, the percentage of children and adolescents in the total population is also systematically declining (Fig. 1). In 1990, this group accounted for $32 \%$, in $2000-27.8 \%$, and in 2017 only $20 \%$ of the total population. The number of live births also decreased from 14.4 per 1000 in 1990 to 10.4 in 2017 [4].

However, in the last two decades, the rate of stillbirths has decreased two-fold, from 7.3 per 1000 live births in 1995 to 2.9 in 2015 [5]. The perinatal mortality rate also decreased from 19.5 per 1000 births in 1990 to 4.8 in 2017.

In 1990-2017 the infant mortality in Poland declined continuously (Fig. 2). In 1990, 10,600 deaths of children under one year of age were registered, while in 2000 3067 , and in 2017 - 1604. The infant mortality rate was 3.99 per 1000 live births in 2017, which was 4.12 lower than in 2000, and more than 15 lower in comparison with 
1990. The average annual rate of decline in infant mortality in Poland in the analysed period was thus approximately $5.7 \%$. Despite this positive trend, the infant mortality rate is still slightly higher than the European Union (EU) average (in 2016 in Poland - 4.0, in the EU - 3.6) [6].

\section{THE HEALTH CARE SYSTEM FOR CHILDREN AND ADOLESCENTS}

\section{HUMAN RESOURCES}

One of the main problems of health care in Poland is the inadequate number of medical personnel. In comparison with other European Union member states, Poland has one of the lowest rates regarding the number of both doctors (2.4) and nurses (5.0) per 1000 citizens (Table 2) [7].

In 2010-2017, the number of paediatricians ranged between 3216 and 3584 (Figs. 3 and 4). As a result of the reform of the health care system from 1999, the role of the paediatrician in primary care has been significantly reduced - it was family doctors and general practitioners who became the main decision-makers in the field of medical care for children. Therefore, a reduction of interest in specialising in the field of paediatrics was observed. In 2014, the law was amended and the paediatrician's leading role in caring for the patient up to the age of 18 years was restored [9].

In addition to primary care, paediatricians provide services in secondary care in general hospitals of various levels. In tertiary care, paediatricians with subspecialties provide services in specialist outpatient clinics or hospitals.

As in the case of doctors, the main problem of nursing care is staff shortage, which will probably increase due to the high average age and successive retirement of nurses, with too few people willing to work in this profession (Fig. 5) [10].

\section{OUTPATIENT HEALTH CARE}

In 2017, outpatient health care was provided in total by 21,685 health centres, 963 individual medical practices, and 4143 individual dental practices. Medical services are provided as part of primary or specialised health care [4].

\section{PRIMARY HEALTH CARE}

Until the end of the 20th century, children were assigned to the outpatient clinic nearest to the place of residence, and only there could they receive primary health

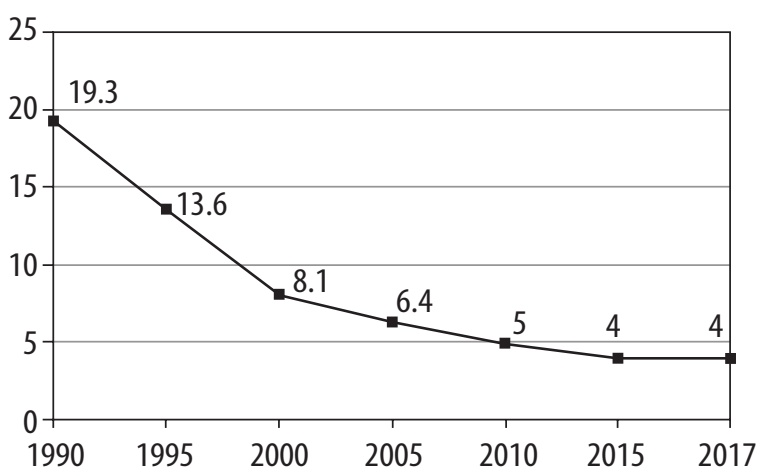

FIGURE 2. Infant deaths per 1000 live births in Poland in the years 1990-2017

care. In the cities, clinics had two separate parts: one for healthy children (assessing the child's development, providing e.g. vaccinations and dietary advice) and one for infectious children. In both sections medical services were provided only by physicians with a specialisation in paediatrics. In rural areas, children were under the care of general practitioners.

Since 1999, when the major reform of the health care system was introduced, primary health care for children was entrusted to physicians with a new specialisation: family medicine. Currently, after several changes in the regulations, children from birth to the age of 18 years can remain under the medical care of family doctors, general practitioners, or paediatricians. Parents and legal guardians of young patients have a guaranteed free choice of doctor.

In 2017, over 169 million medical services were provided in primary health care, of which $21.5 \%$ (36.3 million) were administered to children and young people up to 18 years of age [4].

\section{SPECIALISED HEALTH CARE}

In 2017, over 116 million medical services were provided in specialized health care, of which $12.9 \%$ (nearly 15 million) were administered to children and young people up to 18 years of age.

As part of dental care for children and adolescents nearly 9 million items of medical advice were provided, which was approximately $29 \%$ of the total number of annual dental consultations (34.5 million) [4].

\section{STATIONARY HEALTH CARE}

In 2017, there were 951 general hospitals in Poland with 185.3 thousand beds and 191 day hospitals with

TABLE 2. Medical staff in Poland in the years 2010-2017

\begin{tabular}{|l|c|c|c|c|c|c|c|c|}
\hline Parameter & 2010 & 2011 & 2012 & 2013 & 2014 & 2015 & 2016 & 2017 \\
\hline Physicians & 52,715 & 54,230 & 48,408 & 57,847 & 59,542 & 60,031 & 60,888 & 60,123 \\
\hline Paediatricians & 3216 & 3224 & 3228 & 3236 & 3321 & 3378 & 3624 & 3584 \\
\hline Nurses for 1000 people & 4.79 & 4.84 & 5.49 & 5.21 & 5.17 & 5.14 & 5.10 & 5.04 \\
\hline
\end{tabular}




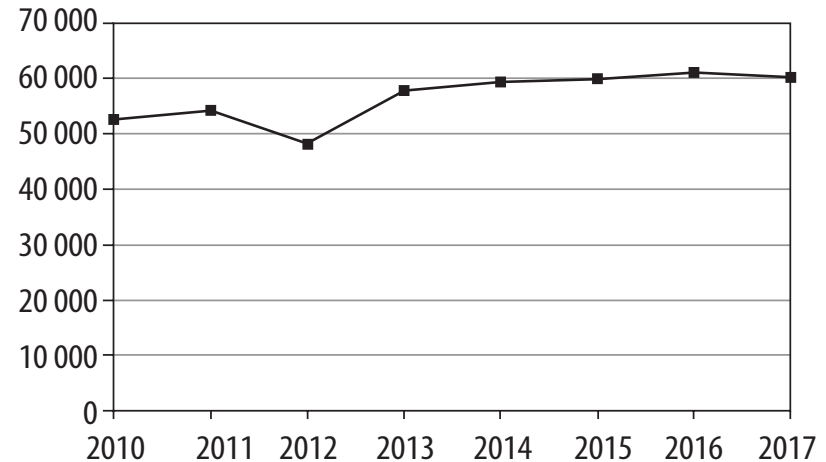

FIGURE 3. Number of physicians in the years 2010-2017

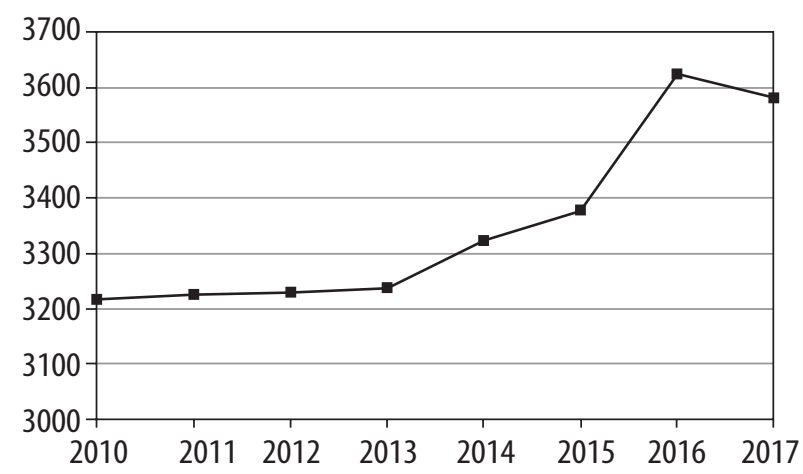

FIGURE 4. Number of paediatricians in the years 2010-2017

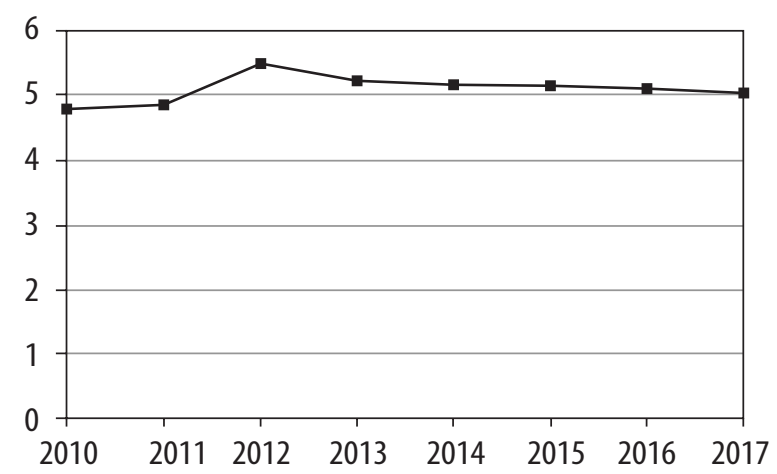

FIGURE 5. Number of nurses per 1000 people in the years 20102017

1.2 thousand day care places. There were 388 paediatric wards and 380 neonatal wards with 9795 paediatric $(5.3 \%$ of all) and 9179 neonatal beds (5.0\%). It should be noted that paediatric wards should have a reserve of beds related to the seasonality of infectious diseases. In comparison to 2010 , the number of paediatric departments decreased by 26 , while the number of neonatal wards remained at the same level. In 2017, 7.8 million patients were hospitalised in general hospitals, with children and adolescents comprising $17.6 \%$ of them [4].

In 2017 the network of essential hospitals was established. It is intended to improve the organisation of providing health care services and increase patients' access to specialist treatment. The network includes 594 hospi- tals - general ones, divided into three levels of reference, along with specialised facilities: paediatrics (13), oncology (20), pulmonology (30) and nationwide multidisciplinary centres (90). Network hospitals have a guaranteed funding from NFZ in a flat-rate form, without the need to compete for financing with other institutions [11]. However, after a year of network functioning, it is difficult to unequivocally evaluate this new solution, because any assessment of its far-reaching impact requires much more time.

\section{HEALTH RESORT TREATMENT}

Health resort treatment in sanatoriums, spa towns, and rehabilitation centres are among the stationary care forms, which are an integral part of the health care system. In 2017, there were 271 health resort centres in Poland, of which $88.6 \%$ provided stationary care. The remaining $11.4 \%$ were outpatient clinics and physiotherapy centres. Younger children, between three and six years old, stay in sanatoriums with their legal guardian, while older children can stay there alone. Sanatoriums provide children with the opportunity to learn at elementary and middle school level, just like boarding schools; therefore, children aged 7-15 years can benefit from treatment throughout the year. Stationary care for adolescents is available during the school-free period.

Despite the undoubted benefits of health resort treatment, the possibility of continuing education and total coverage of treatments, accommodation and meals costs by NFZ, this type of services is not very popular. The main reason is the reluctance to being separated from family and friends, changing the school, and interrupting additional classes. Consequently, despite the great interest in sanatorium treatment in Poland $(734,447$ patients in 2017 ), only $3 \%$ of them are children and adolescents. In recent years, there has been a growing tendency to shut down facilities dedicated to children.

\section{PREVENTIVE HEALTH CARE FOR CHILDREN AND ADOLESCENTS}

In Poland, there is a legal obligation to perform periodic, preventive medical examinations with a comprehensive review of the children's and adolescents' health status, along with an assessment of the regularity of development. In the case of infants, nurses, midwives, and doctors come to the patient's home on so-called patronage visits. This type of health care is provided by primary health care facilities. In addition, there is a nurse or hygienist in every school, who takes preventive care of pupils, performs screening tests, and conducts health education in a broad meaning of this term.

However, according to the data provided by the Centre of Information Systems for Health Care in 2015, almost $14 \%$ of newborns did not have appropriate medical 


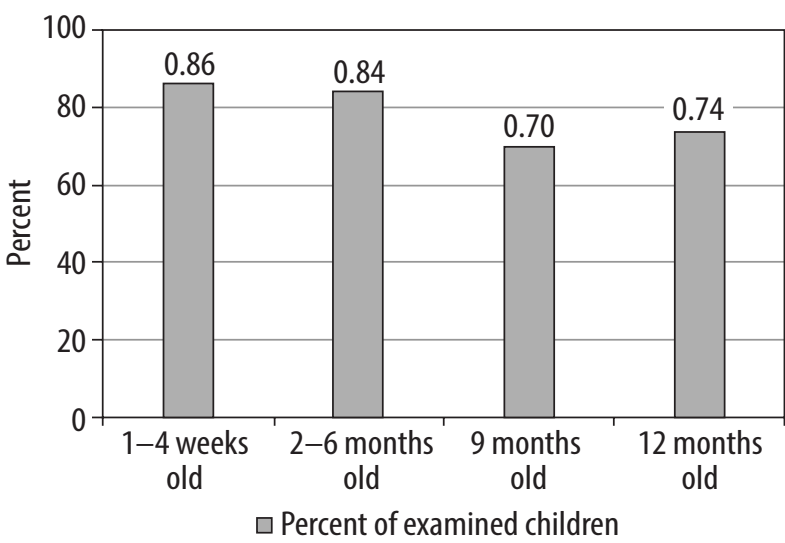

FIGURE 6. Percentage of preventive examined children in the first year of life in 2015

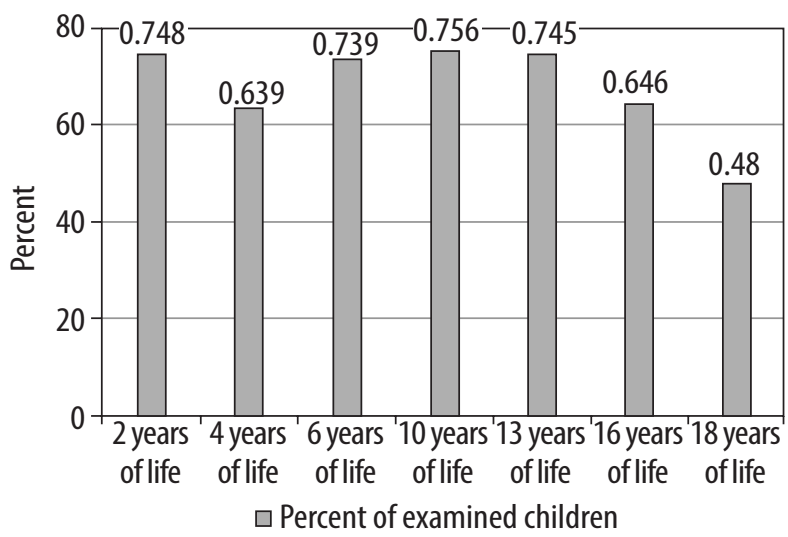

FIGURE 8. Percentage of preventive examined children over one year of age in the years 2010-2015 according to age

care, and this percentage increased with the age of the child, reaching $26 \%$ at the age of one year (Fig. 6) [12].

Preventive examinations carried out in further years concern specific age groups: 2-, 4-, 6-, 10-, 13-, 16-, and 18-year-olds. Regrettably, in all these groups, the percentage of examined children and adolescents is insufficient (Fig. 7). This applies mainly to 4-year-olds (63.9\%), 16 -year-olds (64.6\%), and 18-year-olds (48\%), but also in the remaining age groups it does not exceed 75\% (Fig. 8). In 2010-2015, the percentage of preventive examined children dropped by about $5 \%$ [13]. This may be related to the increasing number of children who are solely under the care of private paediatricians because they are not obliged to report preventive health care actions.

An important element of preventive care is the prevention of infectious diseases, especially by vaccinations. An annually updated vaccination schedule, which contains a list of mandatory and recommended vaccinations, is published by the Chief Sanitary Inspectorate. Since mandatory vaccinations for children are paid for by the state, they are free of charge for the patients, while recommended vaccinations must be purchased by parents or guardians.

In 2016, the following were vaccinated according to the schedule: $98.5 \%$ of children at the age of two years, $97.8 \%$ in the third year of life, $96.9 \%$ at the age of seven years, $93.9 \%$

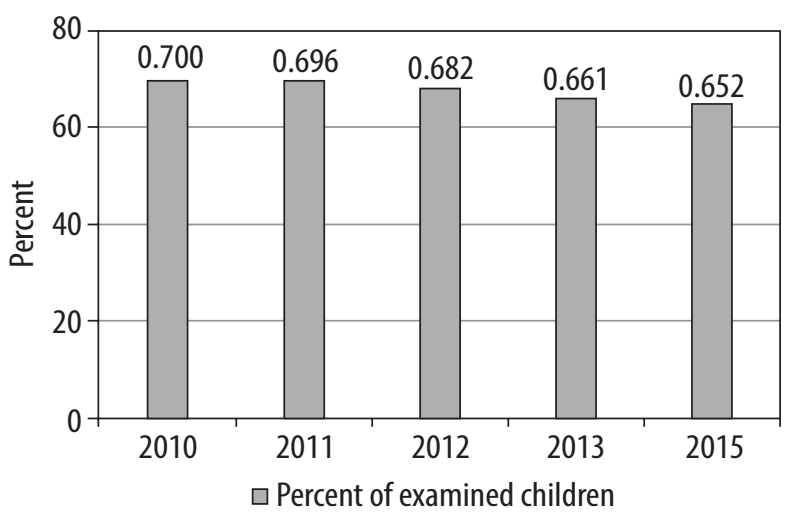

FIGURE 7. Percentage of preventive examined children over one year of age in the years 2010-2015

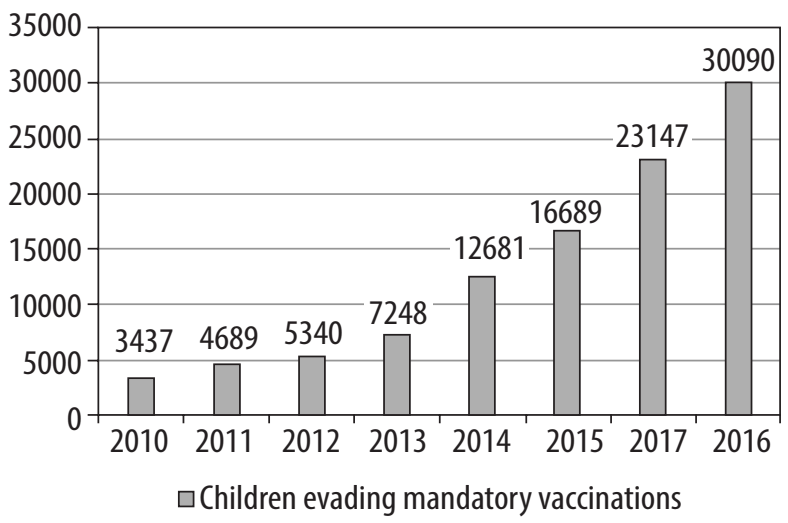

FIGURE 9. Number of children evading mandatory vaccinations in the years 2010-2017

at the age of 11 years, $94.2 \%$ at the age of 15 years, and $93.4 \%$ of girls at the age of 14 years against rubella (Fig. 9) [14]. This high level of vaccinated population (over 90\%) is sufficient to achieve a community resistance and to prevent the epidemic spread of disease. However, although the percentage of people vaccinated in Poland is still high, in recent years more and more parents have been refusing to vaccinate their children, out of fear of adverse effects and under the influence of anti-vaccine movement propaganda [15].

\section{CONCLUSIONS}

Regardless of their insurance status, Polish children and adolescents (0-18-years age group) have an unlimited right to use health care financed from public funds.

An unquestionable success of the Polish health care system is a significant reduction in the infant mortality rate, almost to the average level of the European Union countries, achieved thanks to its average annual decline of about $5.7 \%$ over the last 27 years.

Despite the fact that anti-vaccine movements are gaining more and more supporters around the world, including Poland, the percentage of vaccinated children remains high, and the epidemiological situation of infectious diseases in Poland is relatively favourable and stable. 
Providing children with proper health care is a task that should mainly belong to paediatricians. This applies to both primary and secondary care. Such tasks as careful assessment of the health status of each new-born child, tracking his or her development, and providing full access to preventive care, early diagnosis, and treatment of children's diseases will be best performed by people prepared to provide them. According to the authors, paediatricians are best prepared for this particular type of health care. Therefore, the shortage of these specialists should arouse justified anxiety.

\section{DISCLOSURE}

The authors declare no conflict of interest.

\section{REFERENCES}

1. Constitution of the Republic of Poland. https://www.sejm.gov.pl/ prawo/konst/angielski/kon1.htm (access: 10 March 2019).

2. The United Nations Convention on the Rights of the Child. https:// www.unicef.org.uk/what-we-do/un-convention-child-rights (access: 10 March 2019).

3. Act on health care services financed from public funds of August 27, 2004. http://prawo.sejm.gov.pl/isap.nsf/DocDetails.xsp?id= WDU20042102135 (access: 10 March 2019).

4. Health and Health Care Centre of the Central Statistical Office. http://swaid.stat.gov.pl/SitePagesDBW/ZdrowieOchronaZdrowia. aspx (access: 2 February 2017).

5. Szamotulska K, Mierzejewska E. Zgony niemowląt i noworodków w latach 1995-2015 w Polsce. Dev Period Med 2017; 21: 104-110.

6. Being young in Europe today - health. https://ec.europa.eu/eurostat/statistics-explained/index.php/Being_young_in_Europe_today_-_health (access: 15 February 2019).

7. Health at a Glance: Europe 2018. http://www.oecd.org/health/healthat-a-glance-europe-23056088.htm (access: 27 February 2019).

8. Act amending the Act on health care services financed from public funds and certain other acts of March 21, 2014. http://prawo. sejm.gov.pl/isap.nsf/DocDetails.xsp?id=WDU20140000619 (access: 10 March 2019).

9. Act on primary health care of October 27, 2017. http://prawo.sejm. gov.pl/isap.nsf/DocDetails.xsp?id=WDU20170002217 (access: 10 March 2019).

10. Initial assessment of staff resources of nurses and midwives in Poland by 2020, Supreme Council of Nurses and Midwives. 2010. docplayer.pl/10367693-Wstepna-ocena-w-polsce-do-roku-2020. html (access: 7 February 2019).

11. Act amending the Act on Patient Rights and the Patient Rights Ombudsman and certain other Acts of March 23, 2017. http://prawo. sejm.gov.pl/isap.nsf/DocDetails.xsp?id=WDU20170000836 (access: 10 March 2019).

12. Dzieci się liczą 2017. Raport o zagrożeniach bezpieczeństwa i rozwoju dzieci w Polsce. https://fdds.pl/problem/dzieci-sielicza-2017/ (access: 25 February 2019).

13. Opieka profilaktyczna. https://www.dzieciwpolsce.pl/analiza/9/ opieka-profilaktyczna (access: 12 February 2019).

14. Szczepienia ochronne dzieci i młodzieży. https://stat.gov.pl/ obszary-tematyczne/zdrowie/zdrowie/szczepienia-ochronne-dzieci-i-mlodziezy,19,1.html (access: 18 February 2019).

15. Wojtyniak B, Goryński P. Raport „Sytuacja zdrowotna ludności Polski i jej uwarunkowania”, NIZP-PZH, Warsaw 2018. bazawiedzy. pzh.gov.pl/wydawnictwa (access: 27 February 2019). 